\title{
Identification of Learning Needs of Youth: The case study at the Tourism Village Bejiharjo, Karangmojo, Gunungkidul
}

\author{
Lutfi Wibawa \\ Universitas Negeri Yogyakarta \\ Corresponding e-mail: lutfi_wibawa@uny.ac.id
}

\begin{abstract}
Research identifying learning needs of youth groups in the tourist village aims to reveal the learning needs of aspects of knowledge (knowledge), attitudes and behavior of mental (mental attiude and behavior) in a positive direction and the increase in life skills. This study used a qualitative descriptive approach implemented in the District Tourism Village Bejiharjo Karangmojo Gunungkidul to target youth. Data were collected using focus group discussion (FGD), in-depth interviews, documentation, and observation. The collected data is then analyzed by qualitative descriptive analysis techniques. The results of this study are: First, the need for increased knowledge of learning (knowledge) include: learning materials group dynamics and issues, community development, village history and local knowledge possessed, and adolescent reproductive health. Second, learning to change attitudes and behavior of mental (mental attiude and behavior) in a positive direction include: learning material to improve the courage and confidence, learning mental, spiritual, training cooperation and gotong royong, learning to behave positively, and learning to cultivate self-identity, Third, life skills learning needs include: skills into a good tour guide, foreign language skills, handicraft and souvenirmaking skills, entrepreneurial skills, conflict solving skills and raise skills and to keep the fish.
\end{abstract}

Keywords: Identification, Learning Needs, Youth Groups

\section{INTRODUCTION}

Bejiharjo is a village in Karangmojo subdistrict, Gunung Kidul, Yogyakarta, Indonesia. Bejiharjo consists of 20 hamlets covering Grogol I, Grogol II, Grogol III, Grogol IV, Grogol V, Grogol VI, Gunungsari, Kulwo, Banyubening I, Banyubening II, Ngringin, Karanglor, Karangmojo, Bulu, Gelaran I, Gelaran II, Sokoliman I , Sokoliman II, Gunungbang, and Seropan.

The establishment of a number of Pokdarwis secretariats (tourism awareness groups) that serve tourists to visit the pindul cave is the dominant activity and involves the community. Pindul Cave tourism destination which is increasingly becoming the tourist primadonna, providing benefits and great benefits for the community. So as to create new jobs and livelihood sources of local communities. The people involved in the tourism service activities are not limited to adult men only, but almost all elements of society, women, men, old, young, adolescent.

The emergence of this new tourist destination in addition to providing benefits to the community, also gives negative impact to groups of youth and youth. So to provide the resilience and readiness of youth and adolescents groups in the face of changes that occur in society need to get different kinds of learning programs. Targeted and positive learning programs are always on the forefront of identification of learning needs. It is in this important section that a thorough study of the learning needs of youth and youth groups is needed.

Context of curriculum development, John McNeil (1985) defines need assessment as: "the process by which one defines educational needs and decides what their priorities are", namely the process of determining the priority of education needs. In line with McNeil's opinion, Seel and Glasgow (1990) describe the notion of need assessment "it means a plan for gathering information about discrepancies and for using that information to make decisions about priorities". The need is basically the discrepancies between what is available and what is available and what is expected, and the need assessment is the process of gathering information about the gap and determining the priority of the gap to be solved.

According to Linda J.Smith \&Kristen Drago (2008), Step one of identifying individual training needs is counseling to 
evaluate an employee's position in the organization and what training is necessary for him or her to meet performance goals. The first step of identifying individual training needs counseling to evaluate employee positions in the organization and what kind of training is required for them to fulfill their tasks and responsibilities. Thus, the need assessment is an activity to gather information about the gaps that each student should have with what they already have.

Identification activities are done through the process: First, the preparation of an identification plan containing background, objectives, scope, data collection, location, time, data collection instruments, cost plans, and staff / learning staff. Second, the preparation of a data collection instrument that contains a list of questions about learning needs for target groups. Instruments can be a check list, checklist, interview guide and others as needed.Third, the implementation of the identification to the field is preceded by contacting agencies / institutions / officials / individuals / other subjects related to the collection of data relating to the implementation of the program. After obtaining permission from the authorized official, data collection to the program objectives is obtained. Fourth, the data processing of learning needs in the context of program implementation. Fifth, the compilation of the report on the results of the identification of the implementation of the program containing the background, objectives, scope, achievement of identification results shall include data collection steps, location, time, staff / guardians of learning, type of target and number of achievements, recommendations and follow up, as well as data target attachment of the program result of identification activities.

\section{RELEVANT THEORY AND LITERATURE}

Initial assessment involves the collection of a wide range of information to form a coherent picture of the individual. This information should be used to place them on an appropriate pre-vocational or vocational learning programme which matches their skills, knowledge and abilities, in an appropriate occupational area and to draw up a learning plan which addresses their individual needs. (QPID:2001). The initial assessment involves gathering information to form a coherent picture of the individual.

Jomtien (Goal 5 of the Jomtien World Declaration (UNESCO, 1990): "Expansion of provision of basic education and training in other essential skills required by youth and adults, with programme effectiveness assessed in terms of behavioural changes and impacts on health, employment and productivity". The Jomtien World Declaration made general reference to the learning needs for youth and adults: "The basic learning needs of youth and adults are diverse and should be met through a variety of delivery systems". In the elaboration this article refers to literacy programmes and 'other needs to be served by skills training, apprenticeships, and formal and non-formal education programmes in health, nutrition, population, agriculture al techniques, the environment, science, technology, family life, including fertility awareness, and other societal issues' (UNESCO, 1990: article 5; see also Fordham, 1992).

Another explanation focuses on the results of the analysis so that it can be used in building an agenda aimed at community change that can build the capacity of community-based organizations. The goal of a needs assessment is to identify the assets of a community and determine potential concerns that it faces. A straightforward way to estimate the needs of a community is to simply ask residents their opinions about the development of services within the community, their satisfaction with services, and what particular services are needed. Their opinions can be used in building an agenda aimed at community change that can build the capacity of community-based organizations that are designed to provide its resident's services and development opportunities.(Aparna Sharma B.S, Mindy Lanum B.S., and Yolanda SuarezBalcazar : 2000).

The following is a "how to" guide that briefly details the steps of the Concerns Report Method beginning with the planning phases and ending with implementation of action committees and the utilization of findings from the needs assessment. Ideally, a needs assessment is done in collaboration with local community-based organizations, advocacy groups and/or a university unit. This needs assessment guide is intended to facilitate the work of community leaders, agency staff, and university practitioners in identifying the concerns and strengths of a community and to develop initiatives to address the needs brought forth by the assessment process. 
The needs assessment methodology is divided into four phases that were adapted from Fawcett et al (1987); Balcazar, Keys, Kaplan, and Suarez-Balcazar (1998); and SuarezBalcazar and Orellana (1999). The needs assessment process begins with the planning and organizing phase, data collection, summarizing and disseminating the needs assessment survey results, and sharing the results through public forums to facilitate action planning. Stages of needs analysis include:1). the planning and organizing phase, 2). The needs assessment methodology, 3). Needs assessment survey data collection, 4). Summarizing and disseminating the needs assessment survey results. Learning needs identification includes:

1. Learner analysis (Schwen, 1973; Chen, 2011, p. 94). Learner analysis identifies learner characteristics and individual differences that may have an impact on the learning process (Chen, 2011, p. 94).

2. Context analysis (Dick \& Carrey, 1990; Tessmer, 1990). Context analysis is a systematic review of the settings in which instruction takes place and may involve parameters such as facilities, equipment, and so on.

3. Needs analysis (Rodriguez, 1998; Chen, 2011, p. 94). Needs analysis is used to determine the extent to which a learning need exists by conducting a needs assessment (Chen, 2011, p. 94).

Here the definition adopted is the following: "the entire process of analysis of learning needs and goals and the development of a delivery system to meet those needs. It includes development of instructional materials and activities; and tryout and evaluation of all instruction and learner activities" (Berger, 1996).

\section{METHOD}

This study used a qualitative descriptive approach implemented in the District Tourism Village Bejiharjo Karangmojo Gunungkidul to target youth. Data were collected using focus group discussion (FGD), in-depth interviews, documentation, and observation. The collected data is then analyzed by quantitative and qualitative descriptive analysis techniques. Observation and interview techniques are used to collect local wisdom-values data and conflict-causing data. The data that has been collected is analyzed and described. Implementation of FGD by presenting 25 youth, 5 community leaders, 5 formal leaders and 5 representatives from the tourism conscious group. Observations were conducted to reveal tourism destination management activities. And interviews are done to obtain accurate information related to individual learning needs.

\section{RESULTS AND DISCUSSION}

Bejiharjo village is a village located in District Karangmojo, Gunungkidul district, Special Region of Yogyakarta. Access to Bejiharjo village $5 \mathrm{KM}$ from downtown Wonosari, capital of Gunungkidul Regency. Bejiharjo village has a very exotic natural potential. Unlike most of the areas in Gunungkidul Regency which are faced with limited water resources, Bejiharjo Village has clean water supply throughout the year. The supply of clean water comes from an underground springs source that appears to the surface.

Bejiharjo village also has a rich cultural, historical and educational background. In the eastern part of the village there is the Archaeological site of Sokoliman which is a heritage of science related to ancient human history. At the west end there is the center of Blangkon handicraft, in the middle of the village there is a very rare cultural treasures of Wayang Beber. Around the world Beber Puppet Artefacts live two, one is in Pacitan and the other one is stored in Dusun Gelaran, Bejiharjo Village. In this village there is also a monument that marks the history of the Dutch bombing of Bejiharjo Village.

The bombing was done because Bejiharjo was one of Guerrilla Commander Soedirman's guerrilla route. Bejiharjo village there are 12 nature cave that all have unique one of them is cave Pindul, this cave is inside of the largest stalastite, the most and the most active and panorama of the cave walls are interesting, among others, ornamental stone Curtain, stalastite stones that have been fused with stalasmit that often we call stone Columns, Layers of sandstone, stalastite that grows on the walls of the cave called the rock Cloustum. Panorama and the beauty of Pindul cave we can see in the presence of stone crystals and crystalline stones and curtain wall decorations are round, there are like heart, well, and batik. And we can see the process of the occurrence of stalastic stone and diamond water.

Bejiharjo's natural and cultural wealth has great potential to become a tourist attraction, especially nature tourism, culture and education. Awareness of the great potential that 
became the background of the community and local figures to develop Bejiharjo Village into a tourist village, with a very good nature tourism Pindul cave.

Throughout the 5 years of growth Bejiharjo village became a tourist village showed excellent development. Based on the reports of tourist visitors from time to time have a significant improvement. Along with this development makes Bejiharjo tourist village to be one of the best tourist village destinations in Indonesia.

The development of Bejiharjo village into a phenomenal tourist village brings about changes in society from various aspects, such as research results (Wibawa: 2017)The mindset of the youth on education, with the Tourism cave Pindul made some youths choose to work rather than attend school.

Basing the following field findings can be addressed some learning needs for the youth of the bejiharjo tourist village.

\subsection{The need for learning to increase knowledge}

Youths in the village of Bejiharjo want more knowledge to be able to adapt themselves to the development of society. Several types of new knowledge that become the needs of youth include: 1). Groups and permaslahannya, 2). Community development strategies, 3). Village history and local wisdom, 4). Adolescent reproductive health.

The group's knowledge and its problems, according to Bejiharjo youth, is a knowledge to socialize and mingle with the community. Humans as social beings can never live alone, whether or not humans are part of a group. As social beings who always interact, certainly find the problems, but the various problems in interaction, whether between individuals, between individuals and groups, or interaction between groups can be minimized by knowing the behavior of individuals and groups. This is in line with the problems they face since the village became famous and more and more people came. This condition requires new knowledge relating to the nature of the group and the dynamics that occur within the group.

Knowledge of community development strategies, this knowledge becomes a necessity as a basis for youth to participate in promoting the dynamics of society. Dynamization is intended as an effort to give birth to change towards the better. The community is expected to receive development facilitation as a positive impact of the village as a tourist village. With other untkapan, the progress of village tourism is expected to provide encouragement for the community is also developing towards the better.

Knowledge of village history and local wisdom, this is the village's most precious heritage for children. Local wisdom and village history must become an inherent and unified knowledge of the youth. Bejiharjo village youth are very aware of the importance of this, this knowledge will make themselves more loving youth and have a sense of ownership. The love of the village is important to contribute to the village. The pride of Bejiharjo villagers is embedded as a result of their understanding of history and local wisdom.

Knowledge of reproductive health of adolescent youth, bejiharjo village youth revealed, that with the development of the village into a global tourist attraction, impact on the pattern of interaction is increasingly complex. The large number of tourist visitors from sharing regions and countries, actually bringing diverse cultures. This also affects the pattern of relationships among adolescents. So as to survive from different cultures and patterns of local culture, youth and adolescents need a gambling knowledge of reproductive health. This is to prevent sexual intercourse and uncontrolled sex. With clear reproductive knowledge, youth are expected to be able to distinguish between risky and risky relationships, and more importantly, youth are able to preserve local hereditary cultures, the culture of maintaining self-respect through legitimate relationships.

\subsection{The need for learning to change attitudes and mental behavior in a positive direction}

Needs of learning for youth groups can then be grouped into learning needs in terms of mental attitudes and mental attitudes (mental attitudes and behaviors) in a positive direction. These learning needs include: improving courage and self-confidence, spiritual mental learning, coaching and mutual cooperation, learning to behave positively, and learning to foster self-identity.

Needs of learning to increase courage and confidence, Bejiharo village youth experience minder syndrome or loss of confidence. This condition as a result of interaction with visitors of the tourist village. The youth felt inferior to 
being a village person away from the city. So this condition is realized by the youth to improve themselves and restore their confidence. Awareness for self-confidence is urgent to get, so as not to eliminate the pride of youth as part of the village community. Villagers are no less than other community groups. Proud to be a village youth, from a village able to develop themselves and advance the village into a famous village.

The need for spiritual mental learning, the young people of Bejiharjo village are well aware of the importance of life that is always bound by religious ethics. Religion becomes the most important part in life, because with the teachings of religion, humans find the meaning of life. The values of spirituality become the guidance and guide for life, at least this has been the belief of the Bejiharjo community from the past until now. Youth groups in the village of Bejiharjo need a re-enlightenment about the meaning of religion. This is as a provision for life and keeping the village to stay tied to the values of religion.

The need for cooperative team and gotong royong learning, the youth of the village are aware of the problems they face increasingly complex and diverse. These problems can not be solved with a personal approach, requiring teamwork and mutual cooperation. They are well aware to practice working together and helping each other to alleviate the burden. The concept of gotong royong which is the inheritance of their ancestors must be maintained. So that the village youth felt very needed to practice cooperation and mutual cooperation.

\subsection{Need for life skill learning}

The learning needs of the youth group in Bejiharjo village can then be grouped into the needs of life skills learning, such as: skills to be good tour guides, foreign language skills, craft and souvenir skills, conflict resolution skills and livestock and fish rearing skills. Skill needs of young people and teenagers Bejiharjo village more kusus to adjust and anticipate the development of a tourist village that became a prima donna. These skills are the basic skills they expect to be mastered, as provisions to prepare themselves to be an important part in the development of a tourist village.

\section{CONCLUSION}

Based on the description and discussion in the previous section, some conclusions from the research result titled "Identification of Needs of Youth Learning: Case Study in Bejiharjo Tourism Village, Karangmojo, Gunungkidul", as follows: first, the need for learning to improve knowledge with the material: and its problems, community development strategies, village history and local wisdom, adolescent reproductive health. Second, the need for learning to change attitudes and mental behavior (mental attitudes and behaviour) in a positive direction. These learning needs include: improving courage and self-confidence, spiritual mental learning, coaching and mutual cooperation, learning to behave positively, and learning to foster selfidentity. Third, the need for life skills learning, such as: the skills of being a good tour guide, foreign language skills, craft and souvenir skills, conflict resolution skills and livestock raising skills and fish.

\section{PREFERANCE}

[1] Aparna Sharma B.S, Mindy Lanum B.S., and Yolanda Suarez-Balcazar Ph.D, (2000), A Community Needs Assessment Guide A Brief Guide on How to Conduct a Needs Assessment, Center for Urban Research and Learning and the Department of Psychology Loyola University Chicago.

[2] Hadi Sudjana. (2005). Metode dan Teknik Pembalajaran Partisipatif. Bandung: Falah Production.

[3] QPID, (2001), Department for Education and Employment, Initial Assessment of Learning and Support Needs and Planning Learning to Meet Needs, QPID Dissemination and Marketing Team, Level 3 North, Moorfoot, Sheffield S1 1PQ.

http://dera.ioe.ac.uk/9936/1/Initial assess ment of learning and support needs an d planning learning to meet needs_.pdf

[4] Schwen, T.(1973). Learner analysis: Some process and content concerns. AV Communication Review,21(1), 44-72.

[5] Chen, I. (2011). Instructional design methodologies. In I. Association (Ed.), Instructional design: Concepts, methodologies, tools and applications (pp. 80-94). Hershey, PA: Information Science Reference. 
[6] Tessmer, M. (1990). Environment analysis: A neglected stage of instructional design. Educational Technology Research and Development, 38 (1), 55-64.

[7] Berger, C. (1996). Education 626: Educational software design and authoring Retrieved from http://www.umich.edu/ ed626/define.htm 1

[8] Anna Mavroudi and Thanasis Hadzilacos, (2012),Learning Needs Analysis of Collaborative E-Classes in Semi-Formal Settings:The REVIT Example. http://files.eric.ed.gov/fulltext/EJ1017543 .pdf

[9] Linda J.Smith \&Kristen Drago (2008), Learner Support In Workplace Training, Carl Von Ossietzky University Of Oldenburg, Center For Lifelong Learning (C3L). Sulistiayani, Ambar T. dan Rosidah. (2003). Manajemen Sumber Daya Manusia. Yogyakarta: Graha Ilmu.
[10] Susilo Martoyo. (1994). Manajemen Sumber Daya Manusia. Yogyakarta: BPFE.

[11] UNESCO, 1990. World Declaration on Education for All. Adopted by the World Conference on Education for All meeting Basic Learning Needs. Jomtien ublished by UNESCO for the Secretariat of the International Consultative Forum on Education for All.

[12] Zaenuddin Arif. (2002). Pengelolaan dan Pemberdayaan PKBM. Makalah:

Lokakarya Penyusunan Kurikulum Inti Prodi PLS tanggal 22-24 Agustus 2002 di PPS UNY.

[13] Wibawa, Lutfi. Sujarwo. Hiryanto, (2017), Conflict Resolution Youth Village Tourism Cave Tubing Pindul in Yogyakarta, Atlantis Press (sarl) 29 avenue Laumière 75019 Paris - France http://atlantispress.com/php/pub.php?publication=nfe16. 